2nd International Conference Global Ethics -Key of Sustainability (GEKoS) | May 14, 2021 | Bucharest, Romania

\title{
Financial Inclusion in ASEAN Countries - A Gender Gap Perspective and Policy Prescriptions
}

\author{
Lukman RAIMI, Mirela PANAIT, Eglantina HYSA
}

https://doi.org/10.18662/lumproc/gekos2021/4

How to cite: Raimi, L., Panait, M., \& Hysa, E. (2021). Financial Inclusion in ASEAN Countries - A Gender Gap Perspective and Policy Prescriptions. In A. Grigorescu \& V. Radu (vol. ed.), Lumen Proceedings: Vol. 15. 2nd International Conference Global Ethics - Key of Sustainability (GEKoS) (pp. 38-55). Iasi, Romania: LUMEN Publishing House. https://doi.org/10.18662/lumproc/gekos2021/4 


\title{
Financial Inclusion in ASEAN Countries - A Gender Gap Perspective and Policy Prescriptions
}

\author{
Lukman RAIMI ${ }^{1}$, Mirela PANAIT ${ }^{2 *}$, Eglantina HYSA ${ }^{3}$
}

\begin{abstract}
Financial inclusion is an increasingly intense issue that is of concern to the credit institutions and the public authorities. It has become topical and gained new value during this period of Covid-19 crisis. Although financial exclusion cuts across demographic categories, but certain categories of financial consumers such as women, young people, people with disabilities and those residing in rural areas have a low presence in the financial services sector. Previous studies attribute the incidence of financial exclusion of some segment of the society to low income, low level of financial education or difficult access to financial products and services generated by poor development of physical infrastructure. Is this true in the case of ASEAN region? A quantitative research approach was adopted in this study, while relying on the secondary data of the World Bank spanning 2011-2017, the UN Women ASEAN Gender Outlook report (2020 -2021), and enriched by scholarly works. The article focuses on the dimensions of the phenomenon of financial inclusion in ASEAN countries, with emphasis on the gender gap financial inclusion. The analysis of the extracted data reveals multiple differences among the countries in the region, a fact that can be explained by the different levels of financial technology development and the governmental interventions implemented to improve financial inclusion. On the strength of the findings, this paper argues that digitalization and financial innovation can also be solutions through which new consumers can be attracted to the financial system, but with these solutions come new challenges related to the protection of personal data and cyber security. For this reason, we believe that increasing financial inclusion must be approached at several levels and must involve joint efforts by public authorities, credit institutions and other categories of stakeholders.
\end{abstract}

Keywords: financial inclusion, ASE AN countries, gender gap, development, financial system

\footnotetext{
${ }^{1}$ University Brunei Darussalam (UBD), Brunei Darussalam, Lukman.raimi@,ubd.edu.bn

2*Petroleum-Gas University of Ploiesti \& Institute of National Economy, Romanian Academy, Bucharest, Romania, mirela.matei@upg-ploiesti.ro

${ }^{3}$ Epoka University, Tirana, Albania, ehysa@epoka.edu.al
} 


\section{Introduction}

Due to economic disparities between countries, one can expect that there will be gaps between the developed countries (DCs) and the less developing countries (LDCs) when it comes to innovation (Alfaro et al., 2019), and the birth of successful entrepreneurs (Hysa \& Mansi, 2020), as well as the gap between males and females. At the same time, we find out that the well-being and standards of living are related to the country development, which reflects also in the width of the gender disparity gap (Hoxhaj \& Hysa, 2015; Hysa, 2018). The multidimensional roles of women within the financial system as consumers, business owners, farmers, employees and entrepreneurs have been acknowledged - an indication that they need unhindered access to financial services sector to manage different segments of their livelihoods (Porter et al., 2015; UN Women, 2020). Unfortunately, the gap between women and men with regards to access to formal financial services is widening particularly in developing economies (Pici et al., 2014; Ghosh \& Vinod, 2017; Demirgüç-Kunt et al., 2018; Hysa, 2018; Adegbite \& Machethe, 2020). At the global level the statistics are scary and worrisome. Therefore, the problem of financial inclusion is not only a concern of credit institutions that are trying to attract more and more categories of consumers, but also of governmental authorities in the developed and developing countries (Voica, 2017; Iacovoiu, 2018; Siano et al., 2020; Stancu et al., 2020). Digitalisation of the economy, the bridging of social gaps with corporate social responsibility programs by the financial institutions and the improved women's participation in the labor market are some important factors that have contributed to the reduction of the gender gap regarding financial inclusion in different climes across the globe (Alao \& Raimi, 2011; Raimi et al., 2013; Raimi et al., 2014; Zaman \& Vasile, 2014; Pérez \& delBosque, 2015; Farquhar et al., 2016; Abuladze \& Gigauri, 2017; Damenia et al., 2020; Palazzo et al., 2020; Gigauri \& Damenia, 2020; Gurtu, 2020; Mushkudiani et al., 2020; Gigauri, 2021; Perez et al., 2020; Rehman et al., 2020; Voica \& Stancu, 2021).

In Europe, the research conducted by the European Parliament's Committee on Women's Rights and Gender Equality found that digital gender gap exists in the continent (Davaki, 2018). Moreover, the Global Findex Database for 2017 affirmed that, women are still less likely than men to own an account at financial institutions (Demirgüç-Kunt et al., 2018). In Asia and the Pacific, the gap between men and women with regards to owning an account in a financial institution is almost 30\%, while several countries in the Southeast Asia and Central Asia sub-regions manifest positive development as women are more likely to have accounts than men 
(Sioson \& Kim, 2019). In Sub-Saharan Africa, women have been socially and financially excluded. For instance, in Nigeria, the financial inclusion gender gap was observed to be widening from 7\% in 2011 to $20 \%$ in 2014 , and it further increased to 24\% in 2017 (Adegbite \& Machethe, 2020). The inclusion gender gap widened in Nigeria because of socioeconomic, cultural, institutional, legal and regulatory factors that largely influence the demand and supply of financial services.

Across the Middle East and North Africa region the prevailing custom and legal frameworks have contributed immensely to financial exclusion of women and girls because they are forced to get male signatures on their forms to open bank accounts (Porter et al., 2015).

Overall, the key barriers identified to complicate and perpetuate the financial inclusion gender gap, leading to widening and worsening financial exclusion of women in different regions include among others, lower awareness and knowledge, lower confidence about financial skills/financial literacy (Porter et al., 2015, Adegbite \& Machethe, 2020). The developing countries as well as countries in Europe are experiencing gender disparity with regard to education (Barro \& Lee, 2013). For instance, the average years of schooling per total of population is 11.38 for males and 10.99 for females (Hysa, 2018). Again for Europe, the underlying factors that have engendered the digital exclusion of women and girls include disparity in access to digital services and technologies, inadequate digital skills and education on ICT, gender segregation in the labour market, and inhibiting socio-cultural norms relating threats of harassment, intimidation, surveillance, illegal data retention and cybercrime (Davaki, 2018).

This article intends to investigate financial inclusion gender gap in ASEAN with a view to bridging the gender gap. What Is ASEAN? The word ASEAN connotes the Association of Southeast Asian Nations, which is a regional body with ten members comprising of Brunei, Cambodia, Indonesia, Laos, Malaysia, Myanmar, Philippines, Singapore, Thailand, and Vietnam (Maizland \& Albert, 2020). The ASEAN countries have a total population of 650 million people and an aggregated GDP of $\$ 2.8$ trillion (figure 1). This big market of ASEAN has to be concerned about financial inclusion gender gap as it affects the women and girls, and consequently integrate them into the financial systems because of their important roles in the socio-economic development of ASEAN. 


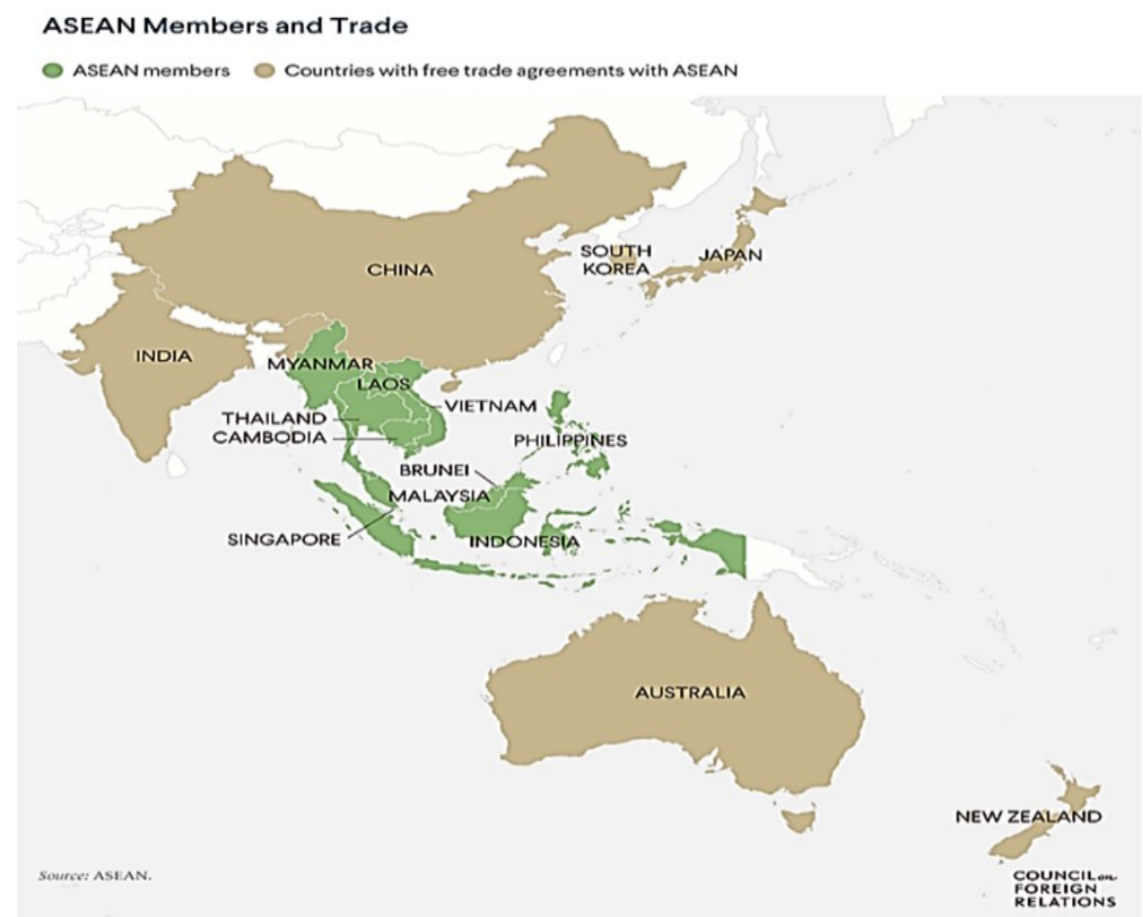

Fig. 1. ASEAN Members and Trade. Source: Maizland \&Albert (2020)

Apart from the introduction (Section 1) above, there are six sections in this paper. Section 2 discusses the problem statement. Section 3 focuses on research questions/aims of the research. Section 4 discusses the research method. Section 5 presents the research findings. Section 6 discusses the conclusion, implications, limitations and policy recommendations.

\section{Problem Statement}

The issue of financial inclusion gender gap needs urgent attention in ASEAN because the region has large share of the world's poverty-ridden people, as 263 million people live on less than $\$ 1.90$ a day and another 1.1 billion live on less than $\$ 3.20$ a day (Asian Development Bank, n.d.). Secondly, financial inclusion gender gap if not redressed and bridged would keep women out of the financial services sector and the development would also hinder inclusive growth and development because financial inclusion of male and female are parts of the benchmarks for the achievement of the Sustainable Development Goals (SDGs) (Hoxhaj et al., 2014; Adegbite \& Machethe, 2020). It is reported that a total of 61.3 million women own and operate businesses of different types within the ten member states of 
ASEAN (United Nations ESCAP, 2017). At the global level, it is reported that women have low participation and visibility in the emerging digital economy because of limited access to digital technologies, low skills on the use of virtual platforms in tapping economic opportunities, pre-occupation with child care, high incidence of gender-based violence, and low labourforce participation (Ntim, 2020). Recent study in the Asia and the Pacific indicated that financial inclusion gender gaps remain large across and within the countries, hence working at redressing the problem is critical for economic development and reduction of poverty and inequality (Loukoianova et al., 2018). From the challenges reported above, there is a need for more researched on the phenomenon in ASEA. This article intends to bridge the knowledge gap that exists in this important field of research in the ASEAN region.

\section{Research Questions/Aims of the research}

The main aim of the article is to investigate financial inclusion gender gap in ASEAN financial service sector including the factors responsible for the gender gap. The following are the overarching research questions that this research intends to provide evidence-based answers for the following questions:

i. What is the level of male-to-female financial inclusion in ASEAN with regards to ownership of accounts, savings, borrowing family or friends, borrowing from a financial institution, ownership of debit cards and ownership of credit cards ( $\%$ age $15+)$ ?

ii. To what extent have the ASEAN countries met the United Nationswide Strategy on Gender Parity of 50\% for each gender

iii. What are the factors responsible for the existence of financial inclusion gender gap?

\section{Research Methods}

The quantitative research method is preferred for this study, as this would allow for objectivity unveiling important facts, trends, and insights on male-to-female financial inclusion in ASEAN. Ten countries, namely, Brunei, Cambodia, Indonesia, Laos, Malaysia, Myanmar, Philippines, Singapore, Thailand and Vietnam are part of ASEAN. Taking into account the availability of the data, eight countries were selected, namely: Cambodia, Indonesia, Malaysia, Myanmar, Philippines, Singapore, Thailand and Vietnam. The secondary data of the World Bank spanning 2011 to 2017 and 
the UN Women ASEAN Gender Outlook report (2020-2021) were used for the study (UN Women, 2021; Demirgüç-Kunt et al., 2018). The data are analysed using descriptive statistics to avoid the problem of statistical inference that often inhibit the replication of most studies. For exploratory research, it suffices to describe accurately how a study was, what data were obtained, what type analysis methods were used and why, and what output those methods produced (Amrhein et al., 2019). Previous studies investigating the phenomenon digital gender gap made use of a descriptive statistics (Davaki, 2018; ILO, 2018; IFC, 2020). The World Bank's database contains numerous indicators for measuring the degree of financial inclusion gender gap. From several gender gap financial inclusion indicators, six indicators were selected and used to determines financial inclusion gender gap and compliance with the $50 \%$ gender parity in ASEAN, Indicators use include:

i. Proportion of male-female with accounts in financial institutions $(\%$ age $15+$ ),

ii. Proportion of male-female with savings in financial institutions $(\%$ age $15+)$,

iii. Proportion of male-female that borrowed from family or friends $(\%$ age $15+)$,

iv. Proportion of male-female that borrowed from financial institutions (\% age $15+)$,

v. Proportion of male-female with debit cards (\% age $15+)$, and

vi. Proportion of male-female with credit cards $(\%$ age $15+)$.

\section{Findings}

Financial inclusion is a complex process, and its dimensions can be measured and tracked with numerous indicators. The most important and commonly used being the share of the population that has opened accounts with financial institutions. At the end of the data analysis, six findings emerged. Firstly, it was found that males and females have accounts with financial institutions in the ASEAN countries. However, the existence of a large number of bank accounts is specific to countries with a higher degree of development, a fact observable in the case of ASEAN countries such as Singapore, Malaysia and Thailand. (Figure 2). Notable differences are registered between women and men, this is explained by the lower share of women in the labor market and also because of the smaller salaries they receive. Notable exceptions are recorded in the Philippines. 


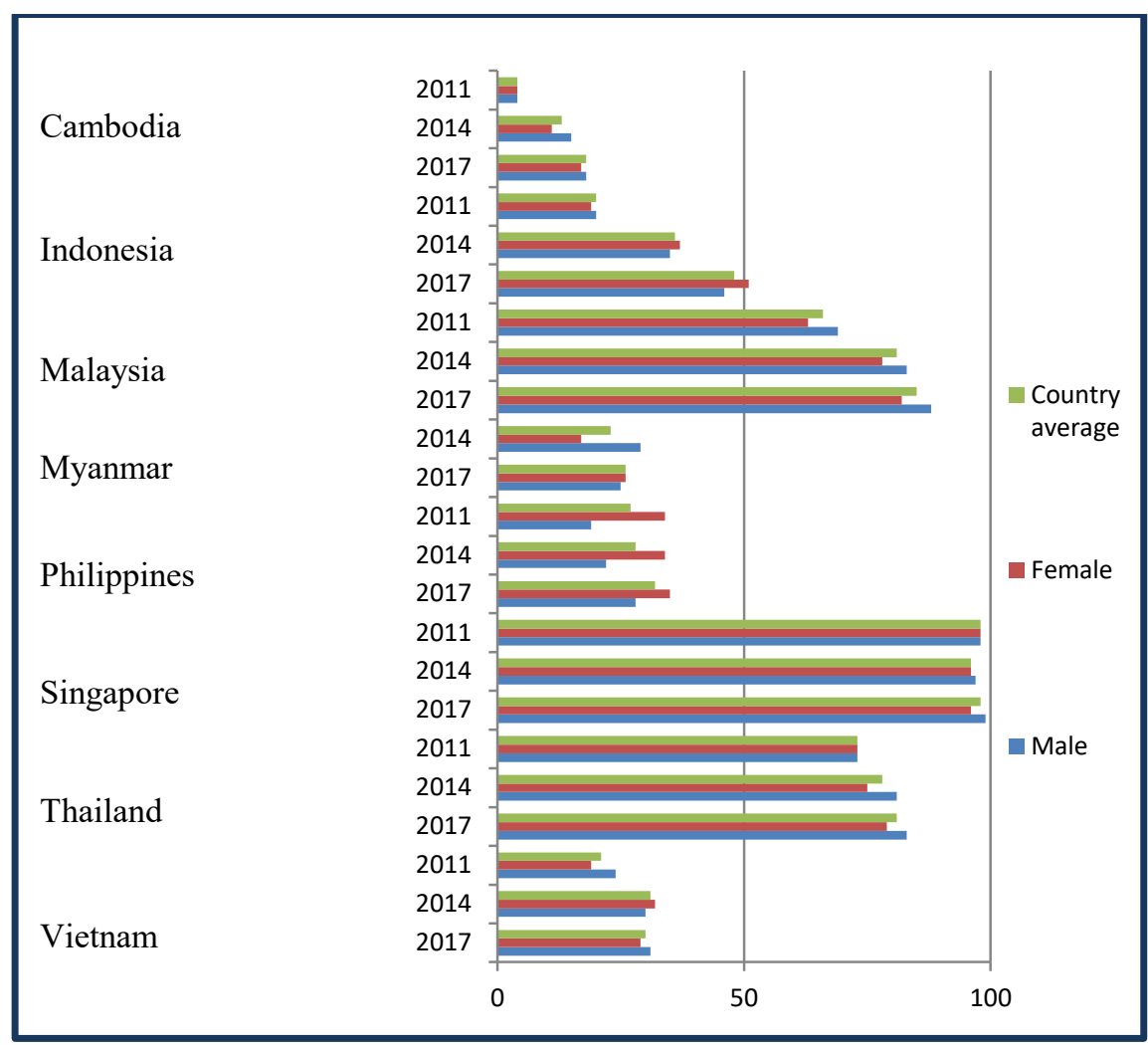

Fig. 2. Financial institution account (\% age 15+); Source: Demirgüç-Kunt et al. (2018)

Secondly, it was found that males and females actually saved with financial institutions in the ASEAN countries. Accounts opened with financial institutions are used for collection of incomes such as salaries, wages, gratuity and pensions, and also for making payments to credit institutions for various things. Encouraging the exluded population especially women to open bank accounts, and actively use the bank accounts for beneficial finnacial services can be done both by the public authorities, women groups, NGOs and financial institutions through financial education and sensitisation programs. The public authorities may legislate that payment of salaries, gratuities and pensions are conditional and premised on opening of bank accounts. More importnatly, the use of bank accounts limits the incidences of money laundering and tax evasion, which are intense phenomena that are remapant in poor countries. The existence of a bank account is essential not only for making online payments but also for stimulating the saving process in developing and emerging markets. 


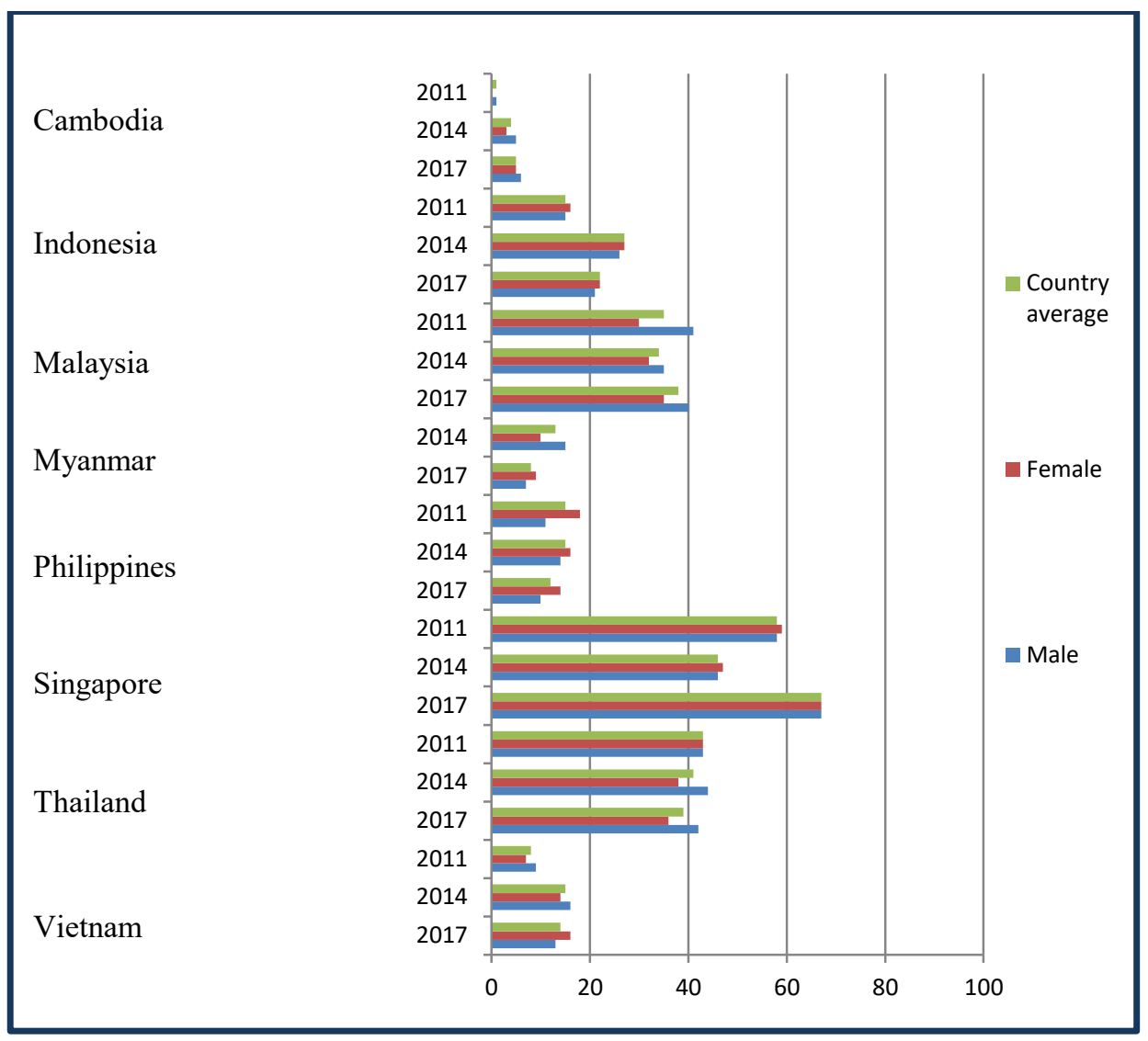

Fig. 3. Saved at a financial institution (\% age 15+); Source: Demirgüç-Kunt et al. (2018)

The highest savings rates are found in Singapore, Malaysia and Thailand (figure 3). This indicates that saving culture is highly encouraged these three countries through satisfactory level of financial education. Financial education is a multifaceted process, which requires not only the science of using financial products but also the ability to save money, even at a modest level. In the case of men, the finding shows that there is a stronger inclination for the saving process, which can be explained by men's level of financial knowledge and higher income.

Thirdly, it was found that males and females borrowed from family or friends in ASEAN for socio-cultural reasons. Loans offered by friends and relatives provide immediate solution for financing short-term business or personal needs. This practice is practised on a large scale in all ASEA countries except Singapore (figure 4). However, borrowing from family and friends is pronounced in both men than women. Moreover, the women 
borrowed from family or friends because of financial exclusion that disenfranchised them from the mainstream financial institutions.

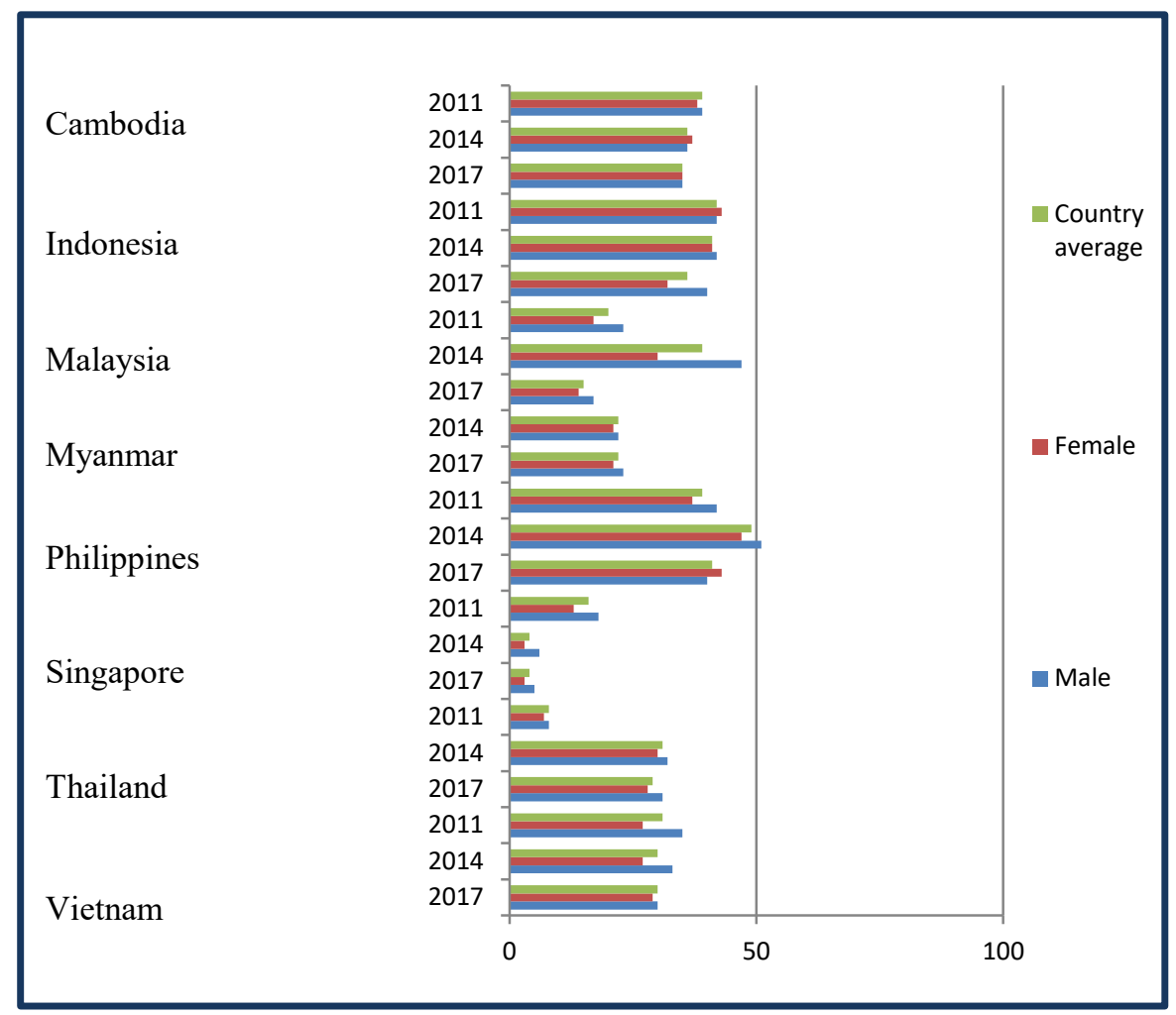

Fig. 4. Borrowed from family or friends ( $\%$ age $15+)$; Source: Demirgüç-

Kunt et al. (2018)

Relying exclusively on the resources of financial institutions is quite rare in the region, and noticeable differences can be observed among the ASEAN countries. Usually, bank loans are accessed by men except Cambodia and Thailand where women are more active in the financial market because of their proactiveness in commercial dealings especially farming, retailing and services. This also demonstrates the importance of the informal economy in the lending process, a fact specific to countries with a lower level of economic development. 


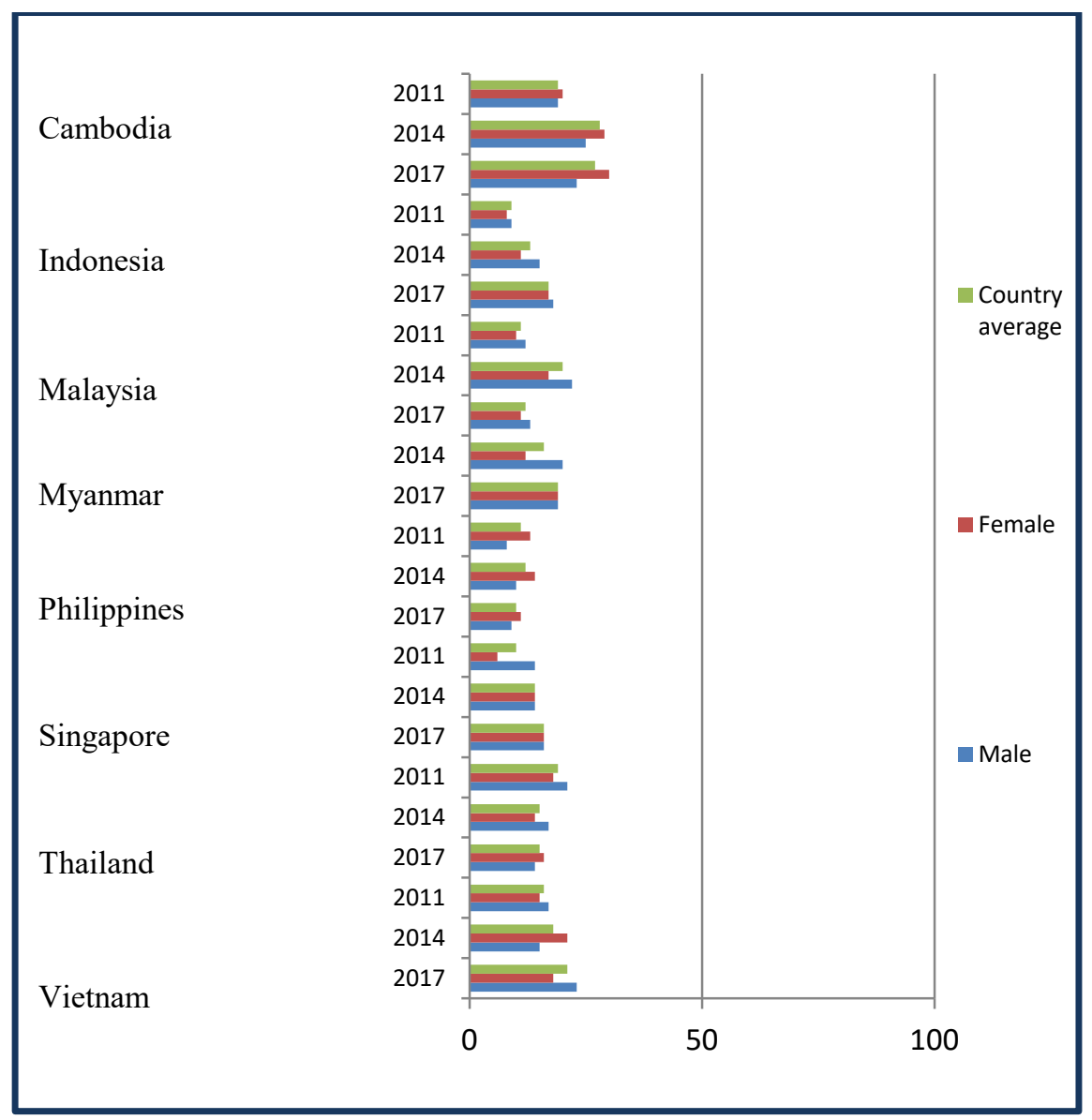

Fig. 5. Borrowed from a financial institution (\% age 15+); Source: Demirgüç-Kunt et al. (2018)

Notable differences are observed among ASEAN countries with regards to share of the population holding debit cards. Singapore and few other countries led other countries in the region on this indicator (figure 6). Overall, men have access to debit cards than women, a gender gap is therefore observed. This is an indication that there is a lower involvement of women in the classic banking operations involved the use debit cards. 


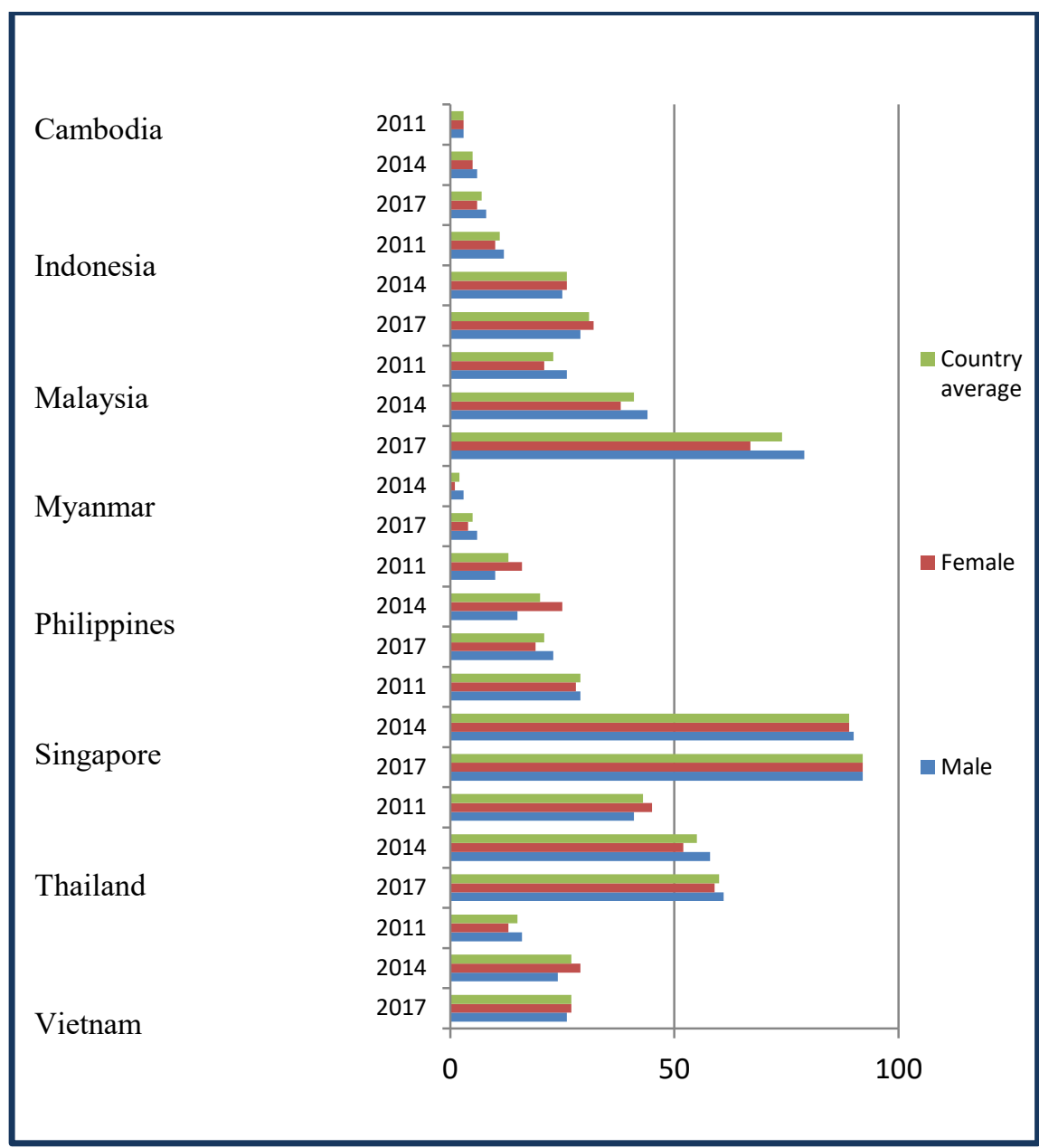

Fig. 6. Debit card ownership (\% age 15+); Source: Demirgüç-Kunt et al. (2018)

In the case of credit cards, the share of the population this financial instrument is very small in all countries in the region (figure 7). This strange finding can be explained by a combination of factors such as consumer reluctance to use credit cards, the preventive attitude of banks, who do not want to offer these products to the banking population because of low level of income and poor financial education. 


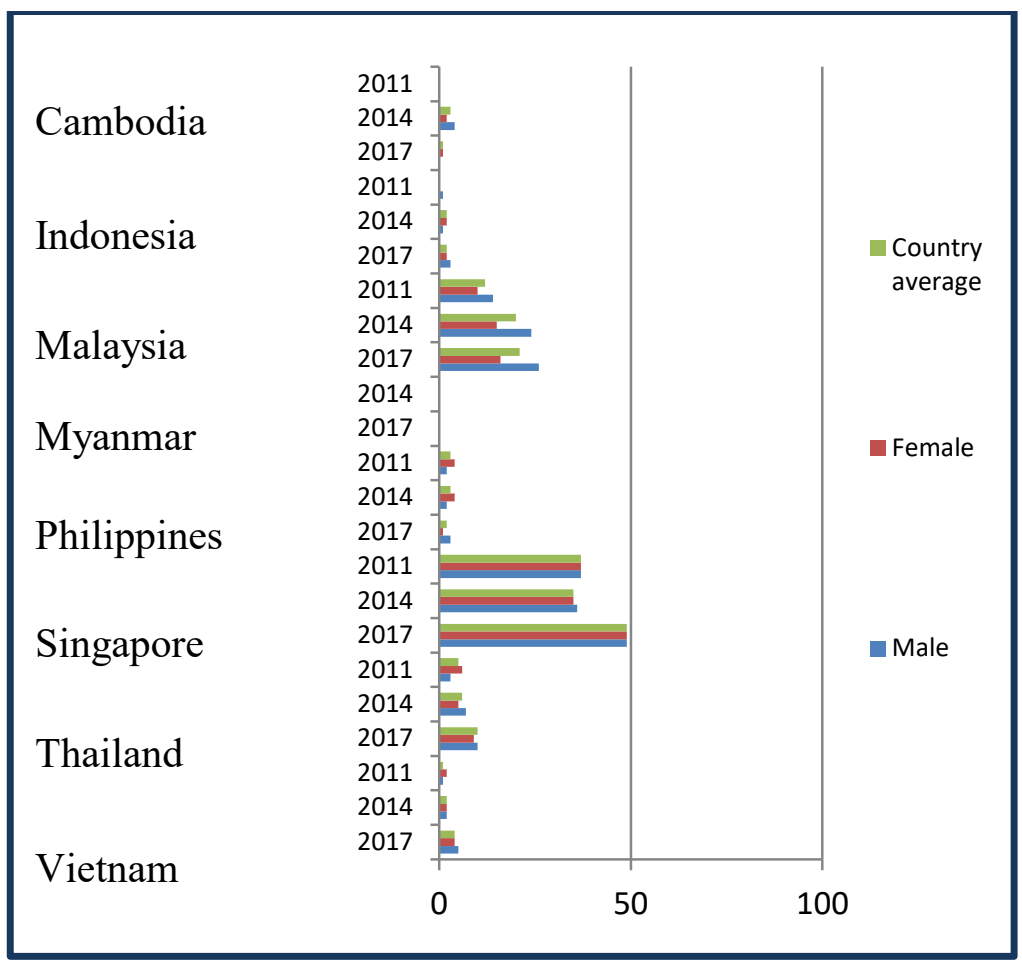

Fig.7. Credit card ownership (\% age 15+); Source: Demirgüç-Kunt et al. (2018)

The indicators of financial inclusion are multiple, and the information reveals the complexity of the phenomenon but also the challenges it generates among the authorities but also the credit institutions.

\section{Conclusions, Limitations and Policy Prescriptions}

The study sets out to investigate the degree of financial inclusion in ASEAN countries with specific focus on gender gap financial inclusion. Six indicators were selected from the multitude of indicators for data analysis. These indicators reveal the existence of financial inclusion gender gap in the proportion of male-female (\% age $15+)$ with accounts in financial institutions; proportion of male-female ( $\%$ age $15+)$ that saved at financial institutions; proportion of male-female (\% age 15+) that borrowed from family or friends, proportion of male-female $(\%$ age $15+)$ that borrowed from financial institutions; proportion of malefemale $(\%$ age $15+)$ with debit cards; and proportion of male-female $(\%$ age 15+) with credit cards. The analysis of the extracted data reveals multiple differences among the countries in the region, a fact that can be 
explained by the different levels of financial technology development and the governmental interventions implemented to increase the degree of financial inclusion.

The paper has few limitations. The first limitation is that only 8 out of the 10 ASEAN countries were analysed, two other countries do not have the requisite data in the database of World Bank and UN Women ASEAN Gender Outlook report. Secondly, the analysis and interpretation of the findings were based on the descriptive statistics. However, future research may consider more rigorous econometric tests that allows researchers to make inferences such as Co-Integration Test, Test of Causality and Inferential Statistics. This is very crucial in order to generate robust findings that would enhance generalisation and prediction.

Although, the current study is by-and-large exploratory, it recommended that a more rigorous studies be conducted in ASEA countries using statistical data that are disaggregated by male-female, urban-rural, educated-less educated and young-old for the purpose of getting a richer and better insight of the gender gap financial inclusion.

i. The policymakers in ASEAN and other developing countries need to identify the factors that engender the gender gap financial inclusion and formulate policies with systematic action plans toward achieving gender equality within a reason number of years.

ii. It is also expedient for the coalition of stakeholders especially public authorities, policy-makers, financial/credit institutions, educational institutions, feminist groups, civil society organisations, and private sector organisations to bridge the worsening gender gap financial inclusion through capacity- building programmes. It is expected that such programmes would develop the capacities and competencies of women and girls in ICT, financial literacy and E-commerce so that they world would be able to tap into the multiple opportunities that the digital technology and financial technology has brought.

iii. The ASEAN governments and ASEAN Economic Community (AEC) should make stronger commitments toward advancing gender equality and parity in the financial service sector and other sectors because gender balance is at the heart of inclusive growth and sustainable development goals (SDG).

\section{References}

Abuladze, R., \& Gigauri, I. (2017). Ecosystem of Digital Economy in Georgia. SSRN Electronic Journal. https://doi.org/10.2139/ssrn.2958038 
Adegbite, O. O., \& Machethe, C. L. (2020). Bridging the financial inclusion gender gap in smallholder agriculture in Nigeria: An untapped potential for sustainable development. World Development, 127, 104755. https://doi.org/10.1016/j.worlddev.2019.104755

Alao, O., \& Raimi, L. (2011). Global economic melt-down and the role of financial institutions. Humanomics, 27(3), 201-211. https://doi.org/10.1108/08288661111165231

Alfaro, E., Yu, F., Rehman, N. U., Hysa, E., \& Kabeya, P. K. (2019). Strategic management of innovation. In J. Chen, A. Brem, E. Viardot, \& P. K. Wong (Eds.) The Routledge Companion to Innovation Management (pp. 107-168). Routledge.

Amrhein, V., Trafimow, D., \& Greenland, S. (2019). Inferential statistics as descriptive statistics: There is no replication crisis if we don't expect replication. The American Statistician, 73(sup1), 262-270.

https://doi.org/10.1080/00031305.2018.1543137

Asian Development Bank. (n.d.). About ADB. https://www.adb.org/who-weare/main

Barro, R. J., \& Lee, J. W. (2013). A new data set of educational attainment in the world, 1950-2010. Journal of Development Economics, 104, 184-198. https://doi.org/10.1016/j.jdeveco.2012.10.001

Damenia, N., Kharaishvili, E., Sagareishvili, N., \& Saghareishvili, M. (2020). Women's Employment Issues in Georgia and Solutions Based on European Experience. International Journal of Economics and Management Engineering, 14(8), 530-

536.https://publications.waset.org/10011342/womens-employmentissues-in-georgia-and-solutions-based-on-european-experience

Davaki, K. (2018). The underlying causes of the digital gender gap and possible solutions for enhanced digital inclusion of women and girls. European Parliament's Policy Department for Citizens' Rights and Constitutional Affairs https://www.europarl.europa.eu/RegData/etudes/STUD/2018/604940/I POL STU(2018)604940_EN.pdf

Demirgüç-Kunt, A., Klapper, L., Singer, D., Ansar, S., \& Hess, J. (2018). The Global Findex Database 2017: Measuring Financial Inclusion and the Fintech Revolution. World Bank. https://globalfindex.worldbank.org/

Farquhar, J., Deigh, L., Palazzo, M., \& Siano, A. (2016). Corporate Research, 19(2), 225-240. https://doi.org/10.1108/QMR-02-2016-0010

Ghosh, S., \& Vinod, D. (2017). What constrains financial inclusion for women? 
Evidence from Indian micro data. World Development, 92, 60-81. https://doi.org/10.1016/j.worlddev.2016.11.011

Gigauri, I. (2021). Corporate Social Responsibility and COVID-19 Pandemic Crisis: Evidence From Georgia. International Journal of Sustainable Entrepreneurship and Corporate Social Responsibility (IJSECSR), 6(1), 30-47. https://doi.org/10.4018/IJSECSR.2021010103

Gigauri, I., \& Damenia, N. (2020). Cooperation between Social Entrepreneurs and Government to Develop Solutions to Social Problems. Business and Economic Research, 10(3). https://doi.org/116-136. 10.5296/ber.v10i3.17383

Gurtu, A. (Ed.). (2020). Recent Advancements in Sustainable Entrepreneurship and Corporate Social Responsibility. IGI Global. https://doi.org/10.4018/978-17998-2347-6

Hoxhaj, J., \& Hysa, E. (2015). Well-being in Developing Countries. International Academic Conference on Social Sciences and Humanities in Prague 2015 (IAC-SSaH 2015 in Prague) AtCzech Technical University in Prague.https://www.researchgate.net/profile/EglantinaHysa/publication/308112884_Wellbeing in Developing Countries/links/57da60df08ae4e6f18413e0c/Wellbeing-in-Developing-Countries

Hoxhaj, J., Bllaci, D., Hodo, M., Pici, E., \& Hysa, E. (2014). Millennium development goals, MDG'S; Case of Kosovo. Mediterranean Journal of Social Sciences, 5(14), 123-123. http://doi.org/10.5901/mjss.2014.v5n14p123

Hysa, E. (2018). Human Capital Trajectory: Performance of Albania and Serbia in catching up the EU countries. Review of Innovation and Competitiveness: $A$ Journal of Economic and Social Research, 4(2), 27-40. https://doi.org/10.32728/ric.2018.42/2

Hysa, E., \& Mansi, M. E. (2020, September 26). The Entrepreneurs' Role in Innovation: Developed versus Developing Countries. XIV IBANESS Congress Series on Economics, Business and Management, Plovdiv, Bulgaria. http://ibaness.org/conferences/plovdiv_2020/ibaness_plovdiv_proceedin gs_draft 5.pdf

Iacovoiu, V. B. (2018). An Empirical Analysis of Some Factors Influencing Financial Literacy. Economic Insights-Trends \& Challenges, 70(2), 23-31. http://upg-bulletin-se.ro/old_site/archive/2018-2/3-Iacovoiu.pdf

International Finance Corporation. (2020). Digital2Equal: Case Studies on Women and the Platform Economy. IFC Gender and Economic Inclusion Group. https://www.ifc.org/wps/wcm/connect/f4a584c1-6eb3-42a2-ba3f- 
Lukman RAIMI et al.| Lumen Proceedings 15 | GEKoS 2021

\section{2c9b5d0a8c9f/202008 D2E_Introduction.pdf?MOD=AJPERES\&CVID} 三nfvwhlo

International Labour Organization. (2018, March). Bridging the Gap: The Gender Gap in Employment: What's Holding Women Back? InfoStories, ILOhttps://www.ilo.org/infostories/en-

GB/Stories/Employment/barriers-women

Loukoianova, M. E., Yang, Y., Guo, M. S., Hunter, M. L., Jahan, M. S., Jamaludin, M. F., ... \& Wu, M. Y. (2018). Financial Inclusion in Asia-Pacific. International Monetary Fund.

Maizland, L., \& Albert, E. (2020, November 24). What Is ASEAN? Backgrounder. Council on Foreign Relations. https://www.cfr.org/backgrounder/whatasean

Mushkudiani, Z., Gechbaia, B., Gigauri, I., \& Gulua, E. (2020). Global, economic and technological trends in human resource management development. Access Journal, 1(1), 53-60. https://doi.org/10.46656/access.2020.1.1(4)

Ntim, C. (2020, September 1). Opinion: 4 ways digital platforms can expand economic opportunity for women. Devex. https://www.devex.com/news/opinion-4ways-digital-platforms-can-expand-economic-opportunity-for-women$\underline{97988}$

Palazzo, M., Vollero, A., \& Siano, A. (2020). From strategic corporate social responsibility to value creation: An analysis of corporate website communication in the banking sector. International Journal of Bank Marketing.volume 38, issue 7, pp. 1529-

\section{2. https://doi.org/10.1108/IJBM-04-2020-0168}

Pérez, A., \& delBosque, I. R. (2015). Customer values and CSR image in the banking industry. Journal of financial services marketing, 20(1), 46-61. https://doi.org/10.1057/fsm.2014.30

Pérez, A., López-Gutiérrez, C., García-De Los Salmones, M. D. M., \& San-Martín, P. (2020). Stakeholder salience, positive CSR news and the market value of banks. Spanish Journal of Finance and Accounting/Revista Española de Financiación y Contabilidad, 49(4), 483-502. https://doi.org/10.1080/02102412.2019.1681718

Pici, E., Pasmaciu, J., Hysa, E., Hoxhaj, J., \& Hodo, M. (2014). Evaluation of millennium development goals process: Case of Albania. Mediterranean Journal of Social Sciences, 5(14), 33-33. https://doi.org/10.5901/mjss.2014.v5n14p33 
Porter, B., Widjaja, N., \& Nowacka, K. (2015). Why technology matters for advancing women's financial inclusion. The Organisation for Economic Cooperation and Development Observer, 303, 33-34.

https://www.proquest.com/openview/2354be64a73e3087b371a01d7c8cff ee $/ 1$ ?pq-origsite $=$ gscholar\&cbl $=35885$

Raimi, L., Patel, A., \& Adelopo, I. (2014). Corporate social responsibility, Waqf system and Zakat system as faith-based model for poverty reduction. World Journal of Entrepreneurship, Management and Sustainable Development, 10(3), 228242. https://doi.org/10.1108/WJEMSD-09-2013-0052

Raimi, L., Shokunbi, M. O., Suara, I. B., \& Fadipe, A. O. (2013). Embedding Islamic Financial System (IFS) in the curricula of schools in Nigeria. Journal of Business Administration and Education, 2(2), 65-84.

http://infinitypress.info/index.php/ibae/article/view/65

Rehman, N. U., Hysa, E., \& Mao, X. (2020). Does public R\&D complement or crowd-out private R\&D in pre and post economic crisis of 2008?. Journal of Applied Economics, 23(1), 349-371. https://doi.org/10.1080/15140326.2020.1762341

Siano, A., Raimi, L., Palazzo, M., \& Panait, M. C. (2020). Mobile Banking: An Innovative Solution for Increasing Financial Inclusion in Sub-Saharan African Countries. Evidence from Nigeria. Sustainability, 12(23), 10130. https://doi.org/10.3390/su122310130

Sioson, E. P., \& Kim, C. J. (2019). Closing the gender gap in financial inclusion through Fintech. Asian Development Bank Institute.

https://www.adb.org/sites/default/files/publication/498956/adbipb2019-3.pdf

Stancu, A., Panait, M., Raimi, L., \& Palazzo, M. (2020, December). Financial Consumers-Promoters of Sustainable Development? Evidences from Europe and Central Asia. In A. M. Dima (Ed.), Innovative Models to Revive the Global Economy (pp. 841-850). Sciendo. https://doi.org/10.2478/9788366675162-083

UN Women (2020) Rapid Assessment Surveys on the Consequences of COVID-19 in Asia and the Pacific. https://data.unwomen.org/resources/surveysshow-covid-19-has-gendered-effects-asia-and-pacific

UN Women. (2021). ASEAN Gender Outlook. Achieving the SDGs for all and leaving no woman or girl behind.

https://data.unwomen.org/sites/default/files/documents/Publications/A SEAN/ASEAN\%20Gender\%20Outlook final.pdf 
United Nations ESCAP. (2017). Fostering Women's Entrepreneurship in ASEAN: Transforming Prospects, Transforming Societies. Report of the Social Development Division. https://www.unescap.org/publications/fosteringwomens-entrepreneurship-asean-transforming-prospects-transformingsocieties\#

Voica, M. C. (2017). Financial inclusion as a tool for sustainable development. Romanian Journal of Economics, 44(1), 121-129. http://revecon.ro/articles/2017-1/2017-1-10.pdf

Voica, M. C., \& Stancu, A. (2021). Corporate Social Responsibility Reporting: Background, Evolution and Sustainability Promoter. In C. F. Macado \& J. P. Davim (Eds.), Sustainable Management for Managers and Engineers (pp. 109155). Wiley-ISTE. https://doi.org/10.1002/9781119804345

Zaman, G., \& Vasile, V. (2014). Economic-financial and social vulnerabilities of Romania in the period 2013-2020. Procedia Economics and Finance, 15, 4-18. https://doi.org/10.1016/S2212-5671(14)00439-0 